\title{
Gouania tiliifolia: The Correct Name for Gouania scandens
}

\author{
Peter B. Phillipson
}

Missouri Botanical Garden, P.O. Box 299, St. Louis, Missouri 63166-0299, U.S.A.; and Muséum national d'Histoire naturelle, Département Systématique et Évolution, UMR 7205, Case Postale 39, 57 rue Cuvier, F-75231 Paris CEDEX 05, France. peter.phillipson@mobot.org

\section{Martin W. Callmander}

Missouri Botanical Garden, P.O. Box 299, St. Louis, Missouri 63166-0299, U.S.A.; and Conservatoire et Jardin botaniques de la ville de Genève, ch. de l'Impératrice 1, 1292 Chambésy, Switzerland

\section{Sven Buerki}

Jodrell Laboratory, Royal Botanic Gardens, Kew, Richmond, Surrey TW9 3DS, United Kingdom

ABSTRACT. In a recent revision of Gouania Jacq. (Rhamnaceae) for Madagascar and other western Indian Ocean islands, confusion about the correct date of publication of Lamarck's Encyclopédie Méthodique caused the authors to overlook the nomenclatural priority of $G$. tiliifolia Lam. over the heterotypic synonym G. scandens (Gaertn.) R. B. Drumm. The error is corrected, and the new combination G. tiliifolia subsp. glandulosa (Boivin ex Tul.) Buerki, Phillipson \& Callm. is provided for its non-typical subspecies.

Resumé. Lors de la récente révision du genre Gouania Jacq. (Rhamnaceae) à Madagascar et incluant les autres îles de l'Océan Indien occidental, une confusion sur la date exacte de publication de l'Encyclopédie Méthodique de Lamarck a eu pour conséquence une omission dans la priorité nomenclaturale de G. tiliifolia Lam. sur le synonyme hétérotypique G. scandens (Gaertn.) R. B. Drumm. Cette erreur est corrigée et la nouvelle combinaison G. tiliifolia subsp. glandulosa (Boivin ex Tul.) Buerki, Phillipson \& Callm. est proposée pour sa sous-espèce non-typique.

Key words: Comoros, Encyclopédie Méthodique, Gouania, Lamarck, Madagascar, Mascarenes, Rhamnaceae.

During the final stages of editorial review of our recently published revision of the genus Gouania Jacq. (Rhamnaceae) for Madagascar and the other western Indian Ocean islands (Buerki et al., 2011), a query was raised about the correct dates of publication of Lamarck's Encyclopédie Méthodique, Botanique. This work, which was published in eight volumes (each comprising one or two parts) between
1783 and 1808, contained descriptions of five species of Gouania in the first part of Volume 3, four of which were described for the first time. Of these, two species, $G$. mauritiana Lam. and $G$. tiliifolia Lam, occur in the region concerned. After careful checking in relevant bibliographic literature (Britten, 1906; Stafleu \& Cowan, 1979) we established that the correct date of publication was 1789 and not 1792 as we had originally stated in our manuscript. Unfortunately, we failed to notice that this correction to the date of publication caused the name $G$. tiliifolia to have priority over the name $G$. scandens (Gaertn.) R. B. Drumm., which was published in 1791 (based on Retinaria scandens Gaertn.). We regard the two taxa to be conspecific, and therefore the first objective of this article is to reinstate $G$. tiliifolia as the correct name for this species. Furthermore, we regard this species to comprise two subspecies differing in only minor morphological characters, but with distinct areas of distribution. We published the new combination $G$. scandens subsp. glandulosa (Boivin ex Tul.) Buerki, Phillipson \& Callm. (based on G. glandulosa Boivin ex Tul.) to accommodate the material from Madagascar with slightly different leaves and stipules and longer floral disc lobes, in comparison with $G$. scandens subsp. scandens from the Mascarenes. The second objective of this article is therefore to publish the necessary new combination for the plant from Madagascar as a subspecies of $G$. tiliifolia.

Gouania tiliifolia Lam. Encycl. (Lamrack) 3: 5. 1789, as "tiliaefolia," non Gouania tiliifolia Rottb. ex DC., 1825, nec Gouania tiliifolia Roxb., 1795 [= Gouania microcarpa DC.]. TYPE: [Réunion Island]. Île Bourbon, s.d. (fl. 
\& fr.), Commerson s.n. (lectotype, designated by Buerki et al. [2011: 188], P-LA!; isolectotype, G!).

Gouania scandens (Gaertn.) R. B. Drumm., Fl. Zambes. 2: 435. 1966. Basionym: Retinaria scandens Gaertn. Fruct. Sem. Pl. 2: 187, tab. 120, fig. 4. 1791. Retinaria volublis Gaertn., Fruct. Sem. Pl. 2: 187, tab. 120, fig. 4. 1791. nom. superfl. Gouania retinaria DC., Prod. (DC.) 2: 40. 1825, nom. superfl. TYPE: [Mauritius] tab. 120, fig. 4 in Gaertn., 1791: 187 (lectotype, designated by Drummond [1966: 435, tab. 120, fig. 4] in Gaertner [1791: 187]).

Gouania tiliifolia Lam. subsp. glandulosa (Boivin ex Tul.) Buerki, Phillipson \& Callm., comb. nov. Basionym: Gouania glandulosa Boivin ex Tul., Ann. Sci. Nat., Bot., sér. 4, 8: 129. 1857 [as "Guania"]. Gouania scandens (Gaertn.) R. B. Drumm. subsp. glandulosa (Boivin ex Tul.) Buerki, Phillipson \& Callm. Ann. Missouri Bot. Gard. 98(2): 190. 2011. TYPE: Madagascar. Toamasina: Sainte-Marie, 1834 (fr.), A. Bernier 239 (lectotype, designated by Buerki et al. [2011: 190], P 00386394!).
Acknowledgments. The authors wish to warmly thank Rafaël Govaerts from the Royal Botanical Gardens, Kew, for pointing out the error in our original publication.

Literature Cited

Britten, J. 1906. Bibliographical notes. XXXIX. The dates of publication of Lamarck's 'Encyclopeidie méthodique' (Botany). J. Bot. 44: 318-320.

Buerki, S., P. B. Phillipson \& M. W. Callmander. 2011. A taxonomic revision of Gouania Jacq. (Rhamnaceae) in Madagascar and the other islands of the western Indian Ocean (the Comoro and Mascarene Islands, and the Seychelles). Ann. Missouri Bot. Gard. 98(2): 157-195.

Drummond, R. B. 1966. Rhamnaceae. Pp. 419-439 in A. W. Exell, A. Fernandes \& H. Wild (editors), Flora Zambesiaca, Vol. 2(2). Crown Agents for Overseas Governments and Administration, London.

Gaertner, J. 1791. De Fructibus et Seminibus Plantarum, Vol. 2: 187. Academiae Carolinae, Stuttgart.

Stafleu, F. \& R. Cowan. 1979. Taxonomic Literature: A Selective Guide to Botanical Publications and Collections with Dates, Commentaries and Types, Vol. 2: H-Le. Bohn, Scheltema \& Holkema, Utrecht. 


\section{$2 \mathrm{BHL}$ Biodiversity Heritage Library}

Phillipson, Peter B, Callmander, Martin W., and Buerki, Sven. 2011. "Gouania tiliifolia : The Correct Name for Gouania scandens." Novon a journal of botanical nomenclature from the Missouri Botanical Garden 21(4), 481-482. https://doi.org/10.3417/2011078.

View This Item Online: https://www.biodiversitylibrary.org/item/180102

DOI: https://doi.org/10.3417/2011078

Permalink: https://www.biodiversitylibrary.org/partpdf/218521

\section{Holding Institution}

Missouri Botanical Garden, Peter H. Raven Library

\section{Sponsored by}

Missouri Botanical Garden

\section{Copyright \& Reuse}

Copyright Status: Permission to digitize granted by rights holder

Rights: https://www.biodiversitylibrary.org/permissions

This document was created from content at the Biodiversity Heritage Library, the world's largest open access digital library for biodiversity literature and archives. Visit BHL at https://www.biodiversitylibrary.org. 